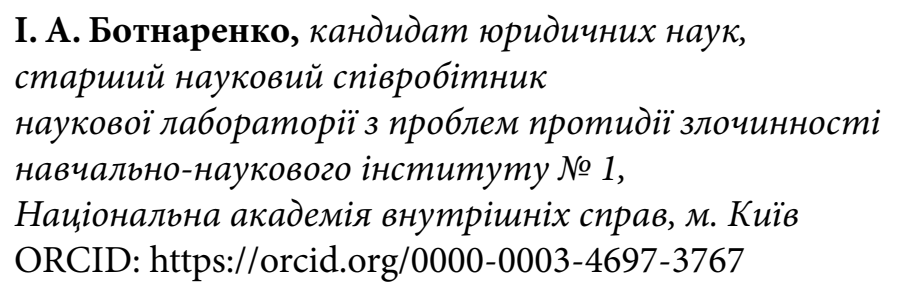

\title{
ДОМАШНЄ НАСИЛЬСТВО: ПОЧАТКОВИЙ ЕТАП РОЗСЛІДУВАННЯ
}

\begin{abstract}
Mema статті - розкрити особливості початкового етапу розслідування кримінальних правопорушень, передбачених ст. $126^{1}$ Кримінального кодексу України, для оптимізації процесу їх розслідування сформувати певні рекомендації. Методологію дослідження становлять загальнонаукові та спеціальні методи наукового пізнання, зокрема: формально-логічним виокремлено обставини, які підлягають встановленню на початковому етапі розслідування домашнього насильства; системно-структурним методом визначено завдання, які вирішуються на початковому етапі розслідування цієї категорії протиправних діянь. Загальні висновки викладено, грунтуючись на методі синтезу. Базисом для застосування всіх методів став діалектичний метод. Наукова новизна. Зроблено спробу виокремити особливості початкового етапу розслідування домашнього насильства через узагальнення обставин, які підлягають встановленню, і визначення системи тактичних завдань, що потребують розв'язання. На підставі цих особливостей сформовано відповідні рекомендації. Висновки. Початковий етап розслідування домашнього насильства спрямований, передусім, на отримання вихідних даних, зокрема оцінювання відомостей про обстановку вчинення, спосіб насильницьких дій, об’єкт злочинного посягання, особу потерпілого, особу кривдника.
\end{abstract}

Ключові слова: домашнє насильство; кримінальне правопорушення; початковий етап розслідування; тактичні завдання; подія кримінального правопорушення; слідчий; потерпілий; кривдник.

\section{Вступ}

Виявлення та розслідування складу кримінального правопорушення, передбаченого ст. $126^{1}$ (Домашнє насильство) Кримінального кодексу України (далі - КК України), коли значна частина інформації, зокрема й через соціальну прийнятність, а то й страх і мовчання членів сім'ї, приховується, потребує особливої уваги й повної мобілізації професійних знань, умінь і навичок слідчих, працівників оперативних та інших підрозділів, що в межах своєї компетенції залучаються до здійснення заходів у сфері протидії таким проявам.

3 питань протидії домашньому насильству (послуговуються також термінами: «сімейне насильство», «насильство в сім'ї», «побутове насильство» - англ. domestic violence, family violence, domestic abuse), що постало особливою міждисциплінарною галуззю вивчення, грунтовно висловлювалися науковці і практики різних країн світу. Серед них: вітчизняні фахівці - А. О. Байда, І. О. Бандурка, О. В. Баранова, І. В. Басиста, О. В. Бойко, В. О. Брижик, А. А. Васильєв, Т. І. Возна, А. А. Вознюк, В. В. Голіна, О. М. Джужа, І. В. Дроздова, М. В. Євсюкова, А. В. Запорожцев, М. Г. Заславська, А. В. Ілліна, А. О. Йосипів, О. В. Ковальова, А. В. Лабунь, О. М. Мусієнко, В. В. Пивоваров, М. І. Рошка, О. Г. Стрельченко, М. І. Хавронюк, Г. О. Христова,
С. С. Чернявський, О. А. Шаповалова, Л. О. Шевченко; США - Е. Гондолф, Р. Парнас, М. Штраус; ФРН - Х. Кури, С. Клаус, У. Шнейдер; Італії Ф. Бруно; Австрії - Л. Логар; Естонії - Я. Соотак та ін. Проблематику домашнього насильства порушено в працях, зокрема: А. Б. Благої (2015 р.), О. М. Ткаленко (2016 р.), М. Г. Кузнєцова (2019 р.), Р. В. Кифлюка (2020р.), окремі аспекти протидії насильству щодо дітей розглядали С. В. Романцова (2018 р.), Н. В. Лесько (2019 р.). У цьому напрямі активізують свої зусилля і зарубіжні колеги (Duggan (Ed.), 2018; Mahapatro, 2018; Nagel, 2019; Nigam, 2019, 2021).

Наразі, досліджуючи проблематику домашнього насильства, науковці акцентують свою увагу на висвітленні, зокрема, таких питань: тактичні завдання розслідування злочинів у сфері службової діяльності (Pchelina, 2016); розуміння домашнього насильства (Duggan (Ed.), 2018; Nagel, 2019); кримінальна відповідальність за домашнє насильство (Vozniuk, 2019); змістовне наповнення терміна «домашнє насильство» (Malynovska, 2020); криміналістична характеристика домашнього насильства (Slukhaienko, 2020); судові експертизи, які призначаються під час розслідування домашнього насильства (Ishchenko, 2020); домашнє насильство в Україні та за кордоном (Pakhomov, \& Bezvin, 2020); перспективність побудови ме- 
тодики розслідування домашнього насильства (Pchelina, 2020); міжнародно-правові стандарти та зарубіжний досвід у сфері запобігання, протидії домашньому насильству (Zinsu, 2021).

Не применшуючи значення наукового доробку вчених з окресленої тематики, зауважимо, що особливості розслідування складу кримінального правопорушення, передбаченого ст. $126^{1}$ КК України, у вітчизняній юридичній науці залишаються поза увагою теоретиків. Надзвичайно мало наукових праць із дослідження особливостей і специфіки кримінальних проваджень, відкритих за ознаками вчинення таких протиправних діянь. Частково проблематики побудови методики розслідування домашнього насильства торкались у своїх наукових розвідках О. В. Пчеліна та Ю. М. Слухаєнко. Разом із тим, зважаючи на загрозливі тенденції зростання зазначених злочинних проявів, що зумовлює необхідність розроблення відповідних рекомендацій щодо розслідування цих правопорушень, порушене питання потребує грунтовного аналізу. При цьому розроблена методика, сформульована за криміналістично значущою ознакою (обстановка вчинення кримінального правопорушення - домашнє насильство), доповнюватиме видові методики, сприяючи оптимізації процесу розслідування.

\section{Мета й завдання дослідження}

Мета статті - розкрити особливості початкового етапу розслідування кримінальних правопорушень, передбачених ст. $126^{1}$ (Домашнє насильство) КК України, для оптимізації процесу їх розслідування сформувати певні рекомендації.

Для досягнення цієї мети необхідно вирішити такі завдання:

визначити систему тактичних завдань, які потребують розв'язання на початковому етапі розслідування правопорушень цієї категорії;

виокремити обставини, які підлягають встановленню на початковому етапі розслідування зазначених протиправних діянь;

для оптимізації процесу розслідування сформувати рекомендації щодо організації початкового етапу розслідування домашнього насильства.

\section{Виклад основного матеріалу}

Процес розслідування домашнього насильства як складу кримінального правопорушення, передбаченого ст. $126^{1}$ КК України, як, власне, й інших кримінальних правопорушень, складається $з$ кількох етапів: початкового, подальшого i завершального. Проте чи не найважливішим убачається початковий, оскільки саме він передбачає комплекс процесуальних і непроцесуальних дій, які безпосередньо впливають на майбутній очі- кувальний результат слідчої діяльності - завершення повного й неупередженого розслідування у встановлені законом строки та визначеної процедури.

Підстави початку досудового розслідування законодавець визначив як «обставини, що можуть свідчити про вчинення кримінального правопорушення» (Kryminalnyi protsesualnyi kodeks, 2012, st. 214, ch. 1). Відповідно обставинами, що можуть свідчити про вчинення кримінального правопорушення, постають ознаки кримінального правопорушення та ознаки складу такого правопорушення. А «для початку досудового розслідування достатньою є, - зауважує Л. М. Лобойко, - мінімально необхідна кількість таких ознак: суспільна небезпека і протиправність (ознаки правопорушення) та об'єкт і об'єктивна сторона (ознаки складу правопорушення)» (Loboiko, 2015, s. 90).

Як стверджують Є. Г. Коваленко та В. Т. Маляренко, «безпосередніми завданнями стадії початкового етапу розслідування $є$ швидке встановлення наявності або відсутності достатніх даних, що вказують на ознаки злочину, а також обставин, що виключають кримінальне провадження, у зв'язку з чим вся робота на цій стадії спрямовується на збирання фактичних даних, які в подальшому має бути визнано достатніми для прийняття рішення по справі» (Kovalenko, \& Maliarenko, 2008, s. 225). Щодо цього слушною убачається позиція О. М. Васильєва, на переконання якого на початку розслідування доцільно користуватися формулою із семи запитань: хто, що, де і з чиєю допомогою, чому, у який спосіб і коли. Надалі ж обставини потрібно встановлювати відповідно до елементів складу злочину, оскільки головне в розслідуванні - встановлення наявності або відсутності складу кримінального правопорушення в діянні особи (Vasilev, 1976, s. 148).

Початковий етап розслідування будь-якого кримінального правопорушення становить наукову категорію криміналістичної науки. Послуговуються нею для позначення періоду досудового розслідування, на якому за допомогою слідчих дій, організаційних та оперативно-розшукових заходів, виконуваних одразу після відкриття кримінального провадження, встановлюють обставини події, які мають ознаки злочинного діяння, необхідні: для орієнтування органів та осіб, що розслідують кримінальне правопорушення; висування версій; планування розслідування; розшуку та затримання злочинця; забезпечення відшкодування збитку; припинення кримінального правопорушення.

А. В. Мазур вважає (і ми не можемо не погодитися з ним), що «на початковому етапі визначають загальний напрям розслідування, висувають та 
перевіряють перші слідчі версії, планують дальші дії. Відповідно до отриманої первинної інформації, наслідків ії перевірки і логічної оцінки орган досудового розслідування визначає першорядні завдання, розробляє стратегію і скеровує весь хід дальшого розслідування» (Mazur, 2015, s. 435).

М. М. Коваль, працюючи над методикою розслідування катувань, слушно стверджує, що «організація розслідування на початковому етапі передбачає переважно роботу з наявною інформацією, iï опрацювання й оцінку» (Koval, 2017, s. 97), відповідно окреслюючи такі його основні завдання: установлення джерела отримання інформації (докладно з'ясовують, хто звернувся із заявою до правоохоронних органів, якщо просто надійшло повідомлення від інших осіб, встановлюють особу, яка потерпіла від конкретного злочину, та осіб, які про це повідомили); збирання інформації про особу потерпілого, що допоможе з'ясувати мотиви та цілі злочинця, а також спосіб, обстановку й місце вчинення злочину; реєстрація заяви та внесення іiі до Єдиного реєстру досудових розслідувань (далі - ЄРДР); у разі можливості огляд місця події (залежить від ситуації, яка склалась, і часу, що минув); оцінювання слідчої ситуації, що дає змогу слідчому визначити та поставити перед собою певні завдання для розслідування конкретного злочину; висування версій відповідно до слідчої ситуації; обрання форм і прийомів взаємодії 3 оперативними службами, залучення спеціалістів; складання плану розслідування (Koval, 2017, s. 98).

Робота слідчого на початковому етапі розслідування домашнього насильства характеризується складністю через суперечливість доказової інформації про більшість фактичних обставин, які стосуються події кримінального правопорушення i винуватості у його вчиненні конкретних осіб, що може вплинути на формування істинного уявлення про вчинене протиправне діяння. Наявної інформації, якою володіє слідчий на початковому етапі розслідування кримінального правопорушення досліджуваної категорії, може бути, засвідчує аналіз слідчої практики, недостатньо для чіткого висновку про обставини вчинення домашнього насильства, а також про дії, що йому передували та мали місце після його закінчення. Тому специфіка розслідування домашнього насильства зумовлюється їх характером, необхідністю детального вивчення не лише обставин самого діяння, особи потерпілої та підозрюваних, а й різних аспектів їх особистого життя. Саме на цьому етапі інформація, яку отримав слідчий, дає змогу висунути версії про сутність розслідуваної події, іiї причини та винних осіб. Тому дії слідчого повинні бути послідовними, логічними та взаємоузгодженими. При цьому, слід зауважити, саме на початковому етапі слідчий має так спланувати слідчі (розшукові) дії, щоб забезпечити можливість отримати об'єктивну інформацію про обставини вчиненого кримінального правопорушення, а також прогнозувати перебіг і результати розслідування.

В узагальненому вигляді до основних завдань початкового етапу розслідування злочинів цієї категорії, убачається, належать: установлення місця, часу і обстановки кримінального правопорушення, його сутності, а також виявлення, фіксація і вилучення його слідів (джерел доказів); установлення, затримання (зокрема й розшук) особи, підозрюваної у вчиненні кримінального правопорушення; збирання доказів, достатніх для повідомлення про підозру (хоча 6 по одному епізоду домашнього насильства).

Є. Г. Сахарова, досліджуючи методику розслідування злочинів, пов'язаних із заподіянням шкоди здоров’ю, вважає, що встановленню підлягають обставини, які стосуються: події злочину; механізму події і його наслідків; особи потерпілого; особи підозрюваного; завданої шкоди (Sakharova, 2015, s. 3997-3999).

Зважаючи на загальні тактичні завдання розслідування будь-якого кримінального правопорушення, наголосимо, що саме на початковому етапі розслідування домашнього насильства слідчий: з'ясовує та перевіряє первинну інформацію про факт домашнього насильства; виявляє, закріплює та зберігає сліди злочину; установлює потерпілих і свідків; реєструє заяву та вносить іiї до ЄРДР; по змозі проводить огляд місця події та висуває первинні слідчі версії; визначає форми і прийоми взаємодії з оперативними службами та відповідними організаціями, а також залучає спеціалістів; складає план розслідування.

Ю. В. Кузьменко, висвітлюючи адміністративний аспект діяльності Національної поліції щодо реалізації Закону України «Про запобігання та протидію домашньому насильству» і шляхи вирішення зазначеної проблеми працівниками поліції, констатує, що «у разі звернення з заявою про домашнє насильство працівники поліції зобов'язані виконати такі дії:

1) увести в Єдиний державний реєстр досудових розслідувань інформацію про подання заяви щодо домашнього насильства;

2) видати потерпілій стороні повідомлення про початок досудового розслідування, в якому буде зазначено номер з Єдиного реєстру;

3) у разі наявності видимих тілесних ушкоджень надати скерування на судово-медичну експертизу;

4) якщо наявні такі ознаки злочину, як нанесення легких чи середньої тяжкості тілесних ушкоджень, мордування, побої, згвалтування, сек- 
суальне домагання та інше, поліцейські повинні розпочати досудове розслідування вчиненого злочину;

5) передати інформацію для Єдиного державного реєстру випадків домашнього насильства та насильства за ознакою статі» (Kuzmenko, 2019. s. 100-101).

До того ж перед виїздом на місце події здійснюється первинна перевірка: змісту та повноти інформації про виклик; повторності викликів у минулому; перебування за адресою виклику осіб, які взяті на профілактичні обліки Національної поліції України (Pamiatka dlia pratsivnykiv, n. d.).

Щодо аналізу матеріалів, які можуть свідчити про вчинення домашнього насильства, то після внесення відповідної інформації до ЄРДР відомості, що містяться в цих матеріалах, оцінюють слідчі за такими критеріями: джерело інформації (від кого отримано інформацію про вчинення домашнього насильства), його походження, зв'язок із подією, яка вивчається, надійність, можливі дефекти відображення ним об’єктивної дійсності (хворобливий стан особи, дефекти сприйняття тощо); зміст інформації, їі повнота, точність, які саме обставини події і наскільки повно висвітлюються в матеріалах; чи не суперечить інформація в наданих матеріалах одна одній.

На стадії збирання та перевірки інформації про факт вчинення домашнього насильства основним тактичним завданням $\epsilon$, передусім, з'ясування наявності достатніх підстав вважати таке діяння кримінальним правопорушенням. О. В. Пчеліна, досліджуючи злочини у сфері службової діяльності, зауважує, що тактичні завдання розслідування «діляться на більш дрібні, які полягають, зокрема, у встановленні наявності суспільно небезпечного діяння, наявності ознак складу конкретного злочину, у встановленні можливих очевидців злочинної події, у пошуку та затриманні злочинця по гарячих слідах тощо» (Pchelina, 2016, s. 157).

Ю. В. Кузьменко конкретизує, що «першою, хто виїжджає на виклики 3 домашнього насильства, є патрульна поліція. Поліція отримує повідомлення на 102, приймає повідомлення з національної гарячої лінії з попередження домашнього насильства, торгівлі людьми та гендерної дискримінації чи з інших джерел та організовує виїзд патрульної бригади на місце правопорушення. У деяких регіонах України першою за цим напрямом на місце події виїжджає створена спеціально група реагування поліції «Поліна». В межах повноважень поліції знаходиться прийом і розгляд заяв про вчинення домашнього насильства» (Kuzmenko, 2019, s. 99).

Заслуговують на увагу рекомендації, запропоновані колективом науковців щодо дій працівників поліції перед виїздом на місце події. Отже, після отримання повідомлення про вчинення домашнього насильства працівнику поліції необхідно: уточнити у заявника дані про характер насильства, учасників сімейного конфлікту, їх стан, необхідність надання медичної допомоги тощо; перевірити за картотекою на предмет перебування осіб, що мешкають за зазначеною адресою, на профілактичних обліках (психічно хворий, наркоман, раніше судимий, особа, якій винесено офіційне попередження про неприпустимість вчинення насильства у сім’ї) та з'ясувати наявність у них зареєстрованої вогнепальної зброї; виїжджати (виходити) на сімейний конфлікт у кількості не менше ніж двох працівників або з громадським помічником дільничного чи членом громадського формування 3 охорони громадського порядку; з'ясувати можливість використання допомоги представників громадського активу, які проживають у будинку, де вчиняється насильство; мати при собі табельну зброю та спеціальні засоби (ПР, БР, «Черемуха», засоби індивідуального захисту) та привести їх у стан, зручний для використання; попередньо розподілити ролі, зважаючи на потреби у взаємному підстрахуванні та кількості учасників конфлікту (Zaporozhtsev et al. (Uklad.), 2012, s. 20).

Безпосередньо на місці події (як першочергові завдання) працівник поліції з'ясовує: ризики загрози життю та здоров’ю членів сім’ї; наявність дітей у помешканні; необхідність направити автомобіль (карету) швидкої медичної допомоги потерпілим; наявність зброї (якщо така є, і можливість її застосування), інших засобів, що загрожують життю та здоров'ю членів родини.

3 моменту виявлення факту вчинення домашнього насильства й упродовж його досудового розслідування слідчий повинен застосовувати всі наявні у нього засоби й методи не тільки для того, щоб зібрати достатню доказову базу, яка б підтверджувала причетність особи до вчинених протиправних діянь, а й припинити їх, а також забезпечити надання необхідної допомоги потерпілому та іншим членам родини. До тактичних завдань початкового етапу розслідування кримінальних правопорушень, передбачених ст. $126^{1}$ КК України, можна віднести: встановлення місця, часу й обстановки вчиненого діяння; виявлення, фіксацію та вилучення слідів цього діяння та речових доказів; встановлення (розшук) і затримання кривдника; встановлення можливих свідків; збирання достатньої доказової бази для повідомлення особі про підозру.

Налагоджуючи контакт з потерпілим, слідчий, передусім, повинен спрямувати свої зусилля на формування в нього впевненості у повній безпеці, а також довіри до правоохоронної системи 
взагалі. Він має усвідомлювати, що правоохоронці серйозно сприймають ситуацію, що склалась, i намагаються відповідно до закону захистити його інтереси. Саме це, на наш погляд, є важливим підгрунтям для початку налагодження контакту та подолання психологічного бар'єру у спілкуванні. Крім того, досить часто родичі та близькі потерпілої особи не дуже співчутливі і належно не усвідомлюють ситуаціі, а то й заперечують факт насильства або проявляють недовіру щодо цього. I єдиним помічником у таких ситуаціях може постати слідчий. Тому слідчий, який здійснює розслідування цієї категорії кримінальних правопорушень, повинен мати глибокі знання у галузі психології та розбиратися в особистісних характеристиках як потерпілих, так і осіб, підозрюваних у вчиненні кримінального правопорушення.

Потерпілій особі, розтлумачуючи іiі права, потрібно пояснити, як вона може захиститися від насильства. При цьому з'ясовують необхідність ії убезпечення, а також вжиття спеціальних заходів щодо кривдника, оформлення матеріалів для подальших процесуальних дій і притягнення правопорушника до відповідальності. А втім, трапляється, особа, яка подає заяву про вчинення домашнього насильства, може надати з різних причин (помста, образа тощо) неправдиві відомості, аби скомпрометувати іншого члена сім’ї. Проте заявник, повідомляючи про факт домашнього насильства, не завжди має на меті притягнути члена своєї родини до кримінальної відповідальності, він може мати лише намір спонукати конкретну особу (члена сім'ї) до вчинення певних дій. Буває, члени сім'ї (найчастіше мати) замовчують факт насильства щодо дітей. Тому особу, аби запобігти завідомо неправдивим повідомленням про факт насильства, попереджають про кримінальну відповідальність (Kryminalnyi kodeks Ukrainy, 2001, s. 383). Крім того, потерпілому надають інформацію про те, яке покарання може бути застосоване до кривдника, роз'яснюють зміст відповідних статей Кримінального кодексу України.

Спілкуючись із потерпілою від домашнього насильства особою, працівник поліції має: заспокоїти ii та іiі дітей, що стали свідками вчинення домашнього насильства; виявляти при цьому повагу, співчуття до неї та розуміння ситуації, намагатися викликати в неї довіру; запевнити, що вона та іiі діти перебувають у безпеці; запропонувати звернутися до лікаря за кваліфікованою медичною допомогою, у разі необхідності й для проведення судово-медичної експертизи (визначення ступеня тяжкості тілесних ушкоджень, тобто так званого «зняття побоїв»); переконати в тому, що відповідно до законодавства жодна людина не має права застосовувати будь-яке насильство до ін- шої особи; порадити звернутися за консультацією до психолога, наголосивши, що під час роботи 3 нею зберігається конфіденційність; за потреби надати повну інформацію про державні (недержавні) установи та організації, які можуть надати підтримку та захист, зокрема й притулок; даючи поради, вказівки тощо, в жодному разі не засуджувати поведінку жертви. Крім того, працівник поліції має уважно спостерігати за тим, як поводяться особи, які перебувають на місці вчинення кримінального правопорушення, і не оцінювати ситуацію, грунтуючись на «першому враженні». При цьому доречно опитати сусідів про обставини інциденту, з'ясувати, чи було таке раніше і чим зазвичай завершувалося.

Якщо необхідно надати психологічну допомогу, інформують відповідний центр соціальних служб для сім'ї, дітей та молоді, центр соціально-психологічної допомоги, притулок для осіб, які постраждали від домашнього насильства та/або насильства за ознакою статі, або мобільну бригаду соціально-психологічної допомоги таким особам (у тому числі шляхом виклику психолога), у разі потреби направити потерпілого до такої спеціалізованої служби підтримки або іншого закладу (установи), що надає послугу притулку.

Безпосередньо спілкуючись 3 особою, яка підозрюється у вчиненні насильства, працівник поліції: насамперед чітко представляється і пояснює доцільність такої бесіди; розмовляє спокійно, урівноважено; у такий спосіб, щоб кривдник усвідомив iі як «сигнал» про те, що він не може розраховувати на подальшу безкарність; наголошує на тому, що застосування будь-яких насильницьких дій має ознаки правопорушення, за яке чинним законом передбачено адміністративну або кримінальну відповідальність.

Крім загальних і окреслених вище обставин, що підлягають з'ясуванню, слідчий із моменту отримання інформації про вчинення домашнього насильства має встановити факти та обставини, які свідчать про кримінальний характер протиправних діянь, і дозволяють правильно їх кваліфікувати, форму насильства, мотиви кримінального правопорушення, віктимологічні риси потерпілого, тривалість насильницьких дій та їхні наслідки тощо.

Для чіткої фіксації фактів насильства на місці події необхідно звернути увагу: на сліди та ознаки насильства (синці, подряпини, кров, рани, опіки, вирване волосся, сліди побиття); стан учасників конфлікту (емоційний стан, алкогольне, наркотичне чи інше сп'яніння, ознаки переляку, жаху, тремтіння рук чи тіла, емоційна неврівноваженість, роздратування, плач, крик, апатія); стан житлового приміщення (сліди крові, розбиті при- 
лади, меблі чи вікна, розкидані речі, розірваний одяг тощо); види знаряддя чи засоби, якими могли бути спричинені ушкодження.

Під час візуального огляду помешкання передусім з'ясовують наявність: місць можливого укриття кривдника або інших осіб, що можуть здійснити раптовий напад на працівника поліції; місць приховування доказів вчинення домашнього насильства, зброї та інших предметів, якими може бути завдано шкоди життю або здоров’ю поліцейського, правопорушника, оточенню; додаткових виходів із приміщення, відкритих вікон на нижніх поверхах, через які правопорушник може втекти або позбавитися речових доказів; ознак перебування собак, яких правопорушник може використати для нападу на поліцейського; місць (приміщень), які можуть бути використані для ізоляції учасників сімейного конфлікту або укриття працівників поліції від нападу правопорушника, зокрема й 3 використанням зброї. Для обмеження доступу до таких предметів доцільно: збільшити відстань між кривдником і цими предметами або ізолювати його в іншому приміщенні; перевести правопорушника в таке місце, щоб він знаходився до них спиною; прибрати такі предмети особисто або за допомогою постраждалої особи.

Отже, збирання криміналістично значущої інформації про подію зазначеного кримінального правопорушення можна звести до з'ясування трьох груп питань: щодо кого вчинено насильство, ким вчинено та у який спосіб.

Визначаючи послідовність окремих слідчих (розшукових) дій, слідчий має керуватися не тільки організаційними, а й тактичними міркуваннями. Перевага віддається діям і заходам, несвоєчасне проведення яких може призвести до пошкодження або знищення речових джерел доказів або їх носіїв.

Початковий етап вирізняється невідкладною необхідністю проводити такі слідчі (розшукові) дії, які забезпечуватимуть виявлення доказової інформації для швидкого, повного та всебічного розслідування. Тому серед першочергових слідчих (розшукових) дій, що можуть бути проведені під час розслідування домашнього насильства, варто виокремити: огляд місця події; освідування; допит потерпілого та свідків; допит підозрюваного.

К. Г. Шеленіна, вивчаючи питання розслідування вбивств, вчинених засудженими в місцях позбавлення волі, наголошувала, що «послідовність початкових слідчих дій залежить безпосередньо від слідчої ситуації. Під час виникнення невідкладного характеру якої-небудь дії, вони повинні бути негайно здійснені, оскільки зволікання може призвести до незворотної втрати можливості отримання доказів» (Shelenina, 2020, s. 606).
За наявності на тілі синців, подряпин, травм, тілесних ушкоджень потерпілого доцільно спрямувати на медичну процедуру огляду побоїв 3 метою виявлення на його тілі слідів чи ознак злочину. Таку процедуру можна здійснити в бюро судово-медичної експертизи. Лікар для встановлення факту заподіяння тілесних ушкоджень i ступеня їх тяжкості оглядає потерпілого i детально фіксує усі травми та сліди побиття. Щоб найбільш точно визначити їх характер і ступінь, звертаються по допомогу впродовж одного-двох днів після отримання ушкоджень. Офіційно визначених часових обмежень щодо цього немає. За результатами такого медичного огляду видають довідку про отримання тілесних ушкоджень, завданих кривдником, що слугуватиме підставою для відкриття кримінального провадження за фактом вчинення протиправного діяння.

У разі заподіяння значної фізичної шкоди здоров’ю потерпілого (як-то тілесних ушкоджень) без зволікання призначають судово-медичну експертизу. «Мета цієї експертизи - не тільки визначення ступеня тяжкості тілесних ушкоджень, а й установлення часу і механізму їх заподіяння, виявлення даних про можливу родову належність використаної зброї або знаряддя (вогнепального, тупого, гострого, колючо-ріжучого тощо), що особливо важливо на початковому етапі розслідування» (Shepitko (Red.), 2010, s. 77).

«Судово-медичне визначення ступеня тяжкості тілесних ушкоджень проводиться, - зазначено у Правилах, затверджених наказом Міністерства охорони здоров'я України від 17 січня 1995 р. № 6, - згідно з Кримінальним та Кримінально-процесуальним кодексами України і цими Правилами» (Pravyla sudovo-medychnoho vyznachennia stupenia tiazhkosti tilesnykh ushkodzhen, 1995).

При цьому слід наголосити, що навіть коли ознак домашнього насильства не встановлено, поліцейські повинні виконати такі дії: винести кривднику офіційне попередження про неприпустимість вчинення насильства в сім'ї; поставити його на профілактичний облік; винести кривднику, який повторно вчинив насильство в сім'ї після отримання офіційного попередження, терміновий заборонний припис; відвідати сім'ю, де чиниться насильство, провести роз'яснювально-виховну роботу з кривдником і проінформувати членів сім’ї про права, заходи й послуги, якими вони можуть скористатися; скласти протокол про вчинення насильства в сім’ї відповідно до норм законодавства України про адміністративні правопорушення (Kodeks Ukrainy pro administratyvni pravoporushennia, 1984, st. $173^{2}$ ).

3 огляду на зазначене вище можна запропонувати такий алгоритм попередньої перевірки 
повідомлень про вчинення домашнього насильства: 1) реєстрація повідомлення про кримінальне правопорушення; 2) виїзд на місце події; 3) 3 дотриманням заходів особистої безпеки вжиття передбачених законом дій із припинення кримінального правопорушення; отримання заяви від потерпілого або особи, яка повідомила про вчинення протиправного діяння; 4) отримання пояснення від кривдника; 5) отримання пояснення від інших учасників та очевидців кримінального правопорушення; 6) огляд місця події (виявлення, фіксація та вилучення слідової інформації); 7) отримання довідки із медичного закладу про факт заподіяння тілесних ушкоджень; 8) з'ясування особистісних характеристик потерпілого та ймовірного кривдника; 9) прийняття рішення про відкриття кримінального провадження.

\section{Наукова новизна}

Зроблено спробу виокремити особливості початкового етапу розслідування домашнього насильства як кримінального правопорушення, передбаченого ст. $126^{1}$ КК України, через узагальнення обставин, які підлягають встановленню, i визначення системи тактичних завдань, що потребують розв'язання. На підставі цих особливостей сформовано відповідні рекомендації щодо організації та розслідування цієї категорії протиправних діянь.

\section{Висновки}

1. Зважаючи на те, що початковий етап розслідування домашнього насильства спрямований, передусім, на отримання вихідних даних, зокрема оцінювання відомостей про обстановку вчинення, спосіб насильницьких дій, об’єкт злочинного посягання, особу потерпілого, особу кривдника тощо, визначено систему тактичних завдань, серед яких:

аналіз наявної (першочергової) інформації та вжиття заходів щодо забезпечення безпеки осіб, які зазнали домашнього насильства;

оцінювання сформованої слідчої ситуації та постановка тактичних завдань щодо розслідування факту домашнього насильства;

виявлення джерел інформації про розслідуване кримінальне правопорушення (матеріальні сліди, знаряддя злочину, свідки-очевидці та ін.); складання плану розслідування та обрання напряму розслідування;

обрання форми і методів взаємодії з органами і службами, що здійснюють заходи у сфері запобігання та протидії домашньому насильству;

пошук і одержання детальної інформації про механізм і обстановку вчиненого правопорушення;

збирання і вивчення відомостей про особу потерпілого (спосіб життя, заняття, зв'язки, зміст дозвілля, риси характеру, поведінка до, під час i після вчинення правопорушення тощо);

пошук, одержання й аналіз інформації про особу, що вчинила правопорушення, iї розшук і затримання;

проведення першочергових слідчих (розшукових) дій (огляд місця події, допит потерпілого та свідків, допит підозрюваного, освідування, призначення експертиз).

2. Обставини, які підлягають встановленню на початковому етапі розслідування домашнього насильства, згруповано за ознаками, що пов'язані: з подією злочину (час, місце, знаряддя, засоби та інші умови вчинення правопорушення); потерпілим; кривдником (персонографічні дані та обставини, які визначають винуватість обвинуваченого, його поведінка до, під час і після вчинення правопорушення, форма вини, мотив і мета злочинної діяльності); наслідками правопорушення (чи заподіяна шкода здоров'ю потерпілого, наявність, характер і тяжкість тілесних ушкоджень або факт смерті тощо).

3. Для оптимізації процесу розслідування сформовано рекомендації щодо організації початкового етапу розслідування цієї категорії протиправних діянь, при цьому, зокрема, уточнено порядок дій слідчого на стадії збирання та перевірки інформації про факт вчинення домашнього насильства.

Отже, початковий етап розслідування домашнього насильства у структурі слідчої діяльності набуває певної ваги, оскільки саме на цьому етапі, коли закладаються основоположні засади для встановлення істини в кримінальному провадженні, виявляється і збирається значна кількість джерел доказової інформації, від ефективності дій слідчого залежить подальший успіх розслідування кримінального провадження.

\section{References}

Duggan, M. (Ed.). (2018). Revisiting the 'Ideal Victim'. In: Developments in Critical Victimology. Policy Press: Bristol. DOI: https://doi.org/10.1332/policypress/9781447338765.003.0010.

Ishchenko, T. V. (2020). Sudovi ekspertyzy, yaki pryznachaiutsia pid chas rozsliduvannia domashnoho nasylstva: analitychnyi ohliad. Visnyk Zaporizkoho natsionalnoho universytetu. Yurydychni nauky, 1, 238-244 [in Ukrainian].

DOI: https://doi.org/10.26661/2616-9444-2020-1-37.

Kodeks Ukrainy pro administratyvni pravoporushennia (statti 1-212²4): Zakon Ukrainy № 8073-X. (1984). Uziato z https:// 
zakon.rada.gov.ua/laws/show/80731-10\#Text [in Ukrainian].

Kovalenko, Ye. H., \& Maliarenko, V. T. (2008). Kryminalnyi protses Ukrainy: pidruchnyk (2-e vyd., pererob. i dopov.). Kyiv: Yurinkom Inter. $712 \mathrm{~s}$. [in Ukrainian].

Koval, M. M. (2017). Metodyka rozsliduvannia katuvan, shcho vchyniaiutsia spivrobitnykamy Natsionalnoi politsii. (Dys. kand. yuryd. nauk). Natsionalnyi universytet «Lvivska politekhnika», Lviv. 237 s. [in Ukrainian].

Kryminalnyi kodeks Ukrainy: Zakon Ukrainy № 2341-III. (2001). Uziato z https://zakon.rada.gov.ua/laws/ show/2341-14 [in Ukrainian].

Kryminalnyi protsesualnyi kodeks Ukrain: Zakon Ukrainy № 4651-VI. (2012). Uziato z https://zakon.rada.gov.ua/laws/ show/4651-17\#n1191 [in Ukrainian].

Kuzmenko, Yu. V. (2019). Administratyvna diialnist Natsionalnoi politsii: protydiia ta zapobihannia domashnomu nasylstvu. Prykarpatskyi yurydychnyi visnyk, 2 (27), 99-102 [in Ukrainian].

DOI: https://doi.org/10.32837/pyuv.v0i2(27).198.

Loboiko, L. M. (2015). Aktualni problemy vyznachennia pidstav i momentu pochatku dosudovoho rozsliduvannia. Visnyk kryminalnoho sudochynstva, 1, 87-92. Uziato z http://nbuv.gov.ua/UJRN/vkc_2015_1_13 [in Ukrainian].

Mahapatro, M. (2018). Understanding Domestic Violence. In: Domestic Violence and Health Care in India. Springer, Singapore.

DOI: https://doi.org/10.1007/978-981-10-6159-2_1.

Malynovska, T. M. (2020). Domashnie nasylstvo: shchodo zmistovnoho napovnennia termina. Nashe pravo, 3, 85-91 [in Ukrainian]. DOI: https://doi.org/10.32782/law.2020.3.14.

Mazur, A. (2015). Mezhi pochatkovoho etapu rozsliduvannia. Visnyk Lvivskoho universytetu. Seriia yurydychna, 61, 435441 [in Ukrainian].

Moskalenko, H. V. (2009). Poniattia ta osoblyvosti etapiv rozsliduvannia zlochyniv. Aktualni problemy derzhavy i prava, 49, 376-380 [in Ukrainian].

Nagel, B. N. (2019). Domestic Violence: Four Home in Hiding: Scenes of Domestic Violence. In Ambiguous Aggression in German Realism and Beyond: Flirtation, Passive Aggression, Domestic Violence (pp. 71-103). New York: Bloomsbury Academic. Retrieved August 27, 2021.

DOI: http://dx.doi.org/10.5040/9781501352744.ch-004.

Nigam, S. (2019). Women and Domestic Violence Law in India: A Quest for Justice (1st ed.). Routledge India. DOI: https://doi.org/10.4324/9780429343575.

Nigam, S. (2021). Domestic Violence Law in India: Myth and Misogyny (1st ed.). Routledge India. DOI: https://doi. org/10.4324/9780429326974.)

Pakhomov, V. V., \& Bezvin, O. S. (2020). Domashnie nasylstvo v Ukraini ta za kordonom. Young Scientist, 3 (79), $295-298$ [in Ukrainian]. DOI: https://doi.org/10.32839/2304-5809/2020-3-79-62.

Pamiatka dlia pratsivnykiv Natsionalnoi politsii «Alhorytm dii politseiskoho v sytuatsii nasylstva». (n. d.). URL: http:// womenua.today/UWC-library/unwomen/4-Police_memory.pdf [in Ukrainian].

Pchelina, O. V. (2016). Taktychni zavdannia rozsliduvannia zlochyniv u sferi sluzhbovoi diialnosti. Aktualni problemy vitchyznianoi yurysprudentsii, 2, 155-158 [in Ukrainian].

Pchelina, O. V. (2020). Perspektyvnist pobudovy metodyky rozsliduvannia domashnoho nasylstva. Yurydychnyi naukovyi elektronnyi zhurnal, 4, 329-332 [in Ukrainian]. DOI: https://doi.org/10.32782/2524-0374/2020-4/79.

Pravyla sudovo-medychnoho vyznachennia stupenia tiazhkosti tilesnykh ushkodzhen: zatv. nakazom MVS Ukrainy № 6. (1995). Uziato z https://zakon.rada.gov.ua/laws/show/z0255-95\#Text [in Ukrainian].

Sakharova, E. G. (2015). Obshchie voprosy rassledovaniia prestuplenii, sviazannykh s prichineniem vreda zdoroviu. Nauchno-metodicheskii elektronnyi zhurnal «Kontcept», 13, 3996-4000 [in Russian].

Shelenina, K. H. (2020). Pochatkovyi etap rozsliduvannia vbyvstv, uchynenykh zasudzhenymy v mistsiakh pozbavlennia voli, ta vidpovidnyi alhorytm dii slidchoho. Porivnialno-analitychne pravo, 1, 602-606 [in Ukrainian]. DOI: https://doi.org/10.32782/2524-0390/2020.1.150.

Shepitko, V. Yu. (Red.). (2010). Kerivnytstvo z rozsliduvannia zlochyniv: nauk.-prakt. posib. Xarkiv: «Odissei». 960 s. [in Ukrainian].

Slukhaienko, Yu. M. (2020). Kryminalistychna kharakterystyka domashnoho nasylstva. Visnyk Luhanskoho derzhavnoho universytetu vnutrishnikh sprav imeni E.O. Didorenka, 3 (91), 295-306 [in Ukrainian]. DOI: https://doi.org/10.33766/2524-0323.91.295-306.

Vasilev, A. N. (1976). Sledstvennaia taktika. M.: Iurid. lit. 200 s. [in Russian].

Vozniuk, A. A. (2019). Kryminalna vidpovidalnist za domashnie nasylstvo: aktualni pytannia teorii ta praktyky. Forum Prava, 55 (2), 6-14 [in Ukrainian]. DOI: https://doi.org/10.5281/zenodo.2635559.

Zaporozhtsev, A. V., Labun, A. V., Zabroda, D. H., Basysta, I. V., Drozdova, I. V., Bryzhyk, V. O., \& Musiienko, O. M. (Uklad.). (2012). Nasylstvo $v$ simi ta diialnist orhaniv vnutrishnikh sprav shchodo yoho podolannia: navch.-metod. posib. dlia kursantiv vyshch. navch. zakladiv MVS Ukrainy. Kyiv. 246 s. 
Zinsu, O. (2021). Mizhnarodno-pravovi standarty ta zarubizhnyi dosvid u sferi zapobihannia, protydii domashnomu nasylstvu. Naukovyi visnyk Natsionalnoi akademii vnutrishnikh sprav, 118 (1), 31-40 [in Ukrainian]. DOI: https://doi.org/10.33270/01211181.31.

\section{Список використаних джерел}

Duggan, M. (Ed.). (2018). Revisiting the 'Ideal Victim'. In: Developments in Critical Victimology. Policy Press: Bristol. DOI: https://doi.org/10.1332/policypress/9781447338765.003.0010.

Іщенко, Т. В. (2020). Судові експертизи, які призначаються під час розслідування домашнього насильства: аналітичний огляд. Вісник Запорізького національного університету. Юридичні науки, 1, 238-244. DOI: https://doi.org/10.26661/2616-9444-2020-1-37.

Кодекс України про адміністративні правопорушення (статті 1-21224): Закон України № 8073-Х. (1984). Узято 3 https://zakon.rada.gov.ua/laws/show/80731-10\#Text.

Коваленко, Є. Г., \& Маляренко, В. Т. (2008). Кримінальний процес України: підручник (2-е вид., перероб. і допов.). Київ: Юрінком Інтер. 712 c.

Коваль, М. М. (2017). Методика розслідування катувань, щз вчиняються співробітниками Національної поліції. (Дис.. канд. юрид. наук). Національний університет «Львівська політехніка», Львів. 237 с.

Кримінальний кодекс України: Закон України № 2341-III. (2001). Узято з https://zakon.rada.gov.ua/laws/ show/2341-14.

Кримінальний процесуальний кодекс України: Закон України № 4651-VI. (2012). Узято з https://zakon.rada.gov.ua/ laws/show/4651-17\#n1191.

Кузьменко, Ю. В. (2019). Адміністративна діяльність Національної поліції: протидія та запобігання домашньому насильству. Прикарпатський юридичний вісник, 2 (27), 99-102. DOI: https://doi.org/10.32837/pyuv.v0i2(27).198.

Лобойко, Л. М. (2015). Актуальні проблеми визначення підстав і моменту початку досудового розслідування. Вісник кримінального судочинства, 1, 87-92. Узято з http://nbuv.gov.ua/UJRN/vkc_2015_1_13.

Mahapatro, M. (2018). Understanding Domestic Violence. In: Domestic Violence and Health Care in India. Springer, Singapore.

DOI: https://doi.org/10.1007/978-981-10-6159-2_1.

Малиновська, Т. М. (2020). Домашнє насильство: щодо змістовного наповнення терміна. Наще право, 3, 85-91. DOI: https://doi.org/10.32782/law.2020.3.14.

Мазур, А. (2015). Межі початкового етапу розслідування. Вісник Львівського університету. Серія юридична, 61, $435-441$.

Москаленко, Г. В. (2009). Поняття та особливості етапів розслідування злочинів. Актуальні проблеми держави $i$ права, 49, 376-380.

Nagel, B. N. (2019). Domestic Violence: Four Home in Hiding: Scenes of Domestic Violence. In Ambiguous Aggression in German Realism and Beyond: Flirtation, Passive Aggression, Domestic Violence (pp. 71-103). New York: Bloomsbury Academic. Retrieved August 27, 2021. DOI: http://dx.doi.org/10.5040/9781501352744.ch-004.

Nigam, S. (2019). Women and Domestic Violence Law in India: A Quest for Justice (1st ed.). Routledge India. DOI: https://doi.org/10.4324/9780429343575.

Nigam, S. (2021). Domestic Violence Law in India: Myth and Misogyny (1st ed.). Routledge India. DOI: https://doi.org/10.4324/9780429326974.

Пахомов, В. В., \& Безвін, О. С. (2020). Домашнє насильство в Україні та за кордоном. Young Scientist, 3 (79), $295-298$. DOI: https://doi.org/10.32839/2304-5809/2020-3-79-62.

Пам’ятка для працівників Національної поліції «Алгоритм дій поліцейського в ситуації насильства». (н. д.). URL: http://womenua.today/UWC-library/unwomen/4-Police_memory.pdf.

Пчеліна, О. В. (2016). Тактичні завдання розслідування злочинів у сфері службової діяльності. Актуальні проблеми вітчизняної юриспрудениї, 2, 155-158.

Пчеліна, О. В. (2020). Перспективність побудови методики розслідування домашнього насильства. Юридичний науковий електронний журнал, 4, 329-332. DOI: https://doi.org/10.32782/2524-0374/2020-4/79.

Правила судово-медичного визначення ступеня тяжкості тілесних ушкоджень: затв. наказом МВС України № 6. (1995). Узято з https://zakon.rada.gov.ua/laws/show/z0255-95\#Text.

Сахарова, Е. Г. (2015). Общие вопросы расследования преступлений, связанных с причинением вреда здоровью. Научно-методический электронный журнал «Кониепт», 13, 3996-4000.

Шеленіна, К. Г. (2020). Початковий етап розслідування вбивств, учинених засудженими в місцях позбавлення волі, та відповідний алгоритм дій слідчого. Порівняльно-аналітичне право, 1, 602-606. DOI: https://doi.org/10.32782/2524-0390/2020.1.150.

Шепітько, В. Ю. (Ред.). (2010). Керівництво з розслідування злочинів: наук.-практ. посіб. Харків: «Одіссей». 960 с.

Слухаєнко, Ю. М. (2020). Криміналістична характеристика домашнього насильства. Вісник Луганського державного університету внутрішніх справ імені Е.О. Дідоренка, 3 (91), 295-306.

DOI: https://doi.org/10.33766/2524-0323.91.295-306. 
Васильев, А. Н. (1976). Следственная тактика. М.: Юрид. лит. 200 с.

Вознюк, А. А. (2019). Кримінальна відповідальність за домашнє насильство: актуальні питання теорії та практики. Форум Права, 55 (2), 6-14.

DOI: https://doi.org/10.5281/zenodo.2635559.

Запорожцев, А. В., Лабунь, А. В., Заброда, Д. Г., Басиста, I. В., Дроздова, І. В., Брижик, В. О., \& Мусієнко, О. М. (Уклад.). (2012). Насильство в сім'ї та діяльність органів внутрішніх справ щзодо його подолання: додаток до навч.-метод. посіб. для курсантів вищ. навч. закладів МВС України. Київ. 56 с.

Зінсу, О. (2021). Міжнародно-правові стандарти та зарубіжний досвід у сфері запобігання, протидії домашньому насильству. Науковий вісник Національної академї внутрішніх справ, 118 (1), 31-40. DOI: https://doi.org/10.33270/01211181.31.

Стаття надійшла до редакції 15.06.2021

\author{
I. Botnarenko, $P h D$ (Law), \\ Senior Researcher \\ Scientific Laboratory on Crime Prevention \\ Educational and Scientific Institute № 1, \\ National Academy of Internal Affairs, Kyiv, Ukraine \\ ORCID: https://orcid.org/0000-0003-4697-3767
}

\title{
DOMESTIC VIOLENCE: THE INITIAL STAGE OF THE INVESTIGATION
}

The purpose of the article to reveal the features of the initial stage of the investigation of criminal offenses under Art. 1261 of the Criminal code of Ukraine, for optimization of process of their investigation to form certain recommendations. The research methodology is made up of various general scientific and special methods of scientific knowledge, in particular: the circumstances that are to be established at the initial stage of the investigation of criminal offenses related to domestic violence are formally and logically highlighted; the system-structural method defines the tasks that are solved at the initial stage of the investigation of this category of unlawful acts. General conclusions are presented based on the synthesis method. The dialectical method became the basis for the application of all methods. Scientific novelty. An attempt is made to highlight the features of the initial stage of the investigation of domestic violence by summarizing the circumstances to be established and defining the system of tactical tasks that need to be addressed. Based on these features, appropriate recommendations have been formed. Conclusions. The initial stage of the investigation of criminal offenses related to domestic violence is aimed primarily at obtaining initial data, in particular, at assessing information about the situation of the commission, the method of violent actions, the object of the criminal attack, the identity of the victim, the identity of the offender.

Keywords: domestic violence; domestic violence criminal offense; the initial stage of the investigation; tactical tasks; crime event; investigator; victim; offender. 
И. А. Ботнаренко, кандидат юридических наук, старший научный сотрудник таборатории по проблемам противодействия преступности учебно-научного института № 1 , Национальная академия внутренних дел, г. Киев ORCID: https://orcid.org/0000-0003-4697-3767

\section{ДОМАШНЕЕ НАСИЛИЕ: ПЕРВОНАЧАЛЬНЫЙ ЭТАП РАССЛЕДОВАНИЯ}

Цель статьи - раскрыть особенности первоначального этапа расследования уголовных преступлений, предусмотренных ст. $126^{1}$ Уголовного кодекса Украины, для оптимизации процесса их расследования сформировать определенные рекомендации. Методологию исследования составляют различные общенаучные и специальные методы научного познания, в частности: формально-логическим выделены обстоятельства, подлежащие установлению на начальном этапе расследования домашнего насилия; системно-структурным методом определены задачи, которые решаются на начальном этапе расследования этой категории противоправных деяний. Общие выводы изложены, основываясь на методе синтеза. Основой для применения всех методов стал диалектический метод. Научная новизна. Сделана попытка выделить особенности первоначального этапа расследования домашнего насилия через обобщение обстоятельств, подлежащих установлению, и определение системы тактических задач, требующих решения. На основании этих особенностей

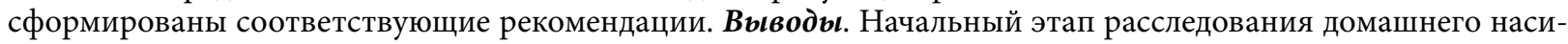
лия направлен прежде всего на получение исходных данных, в частности на оценку сведений об обстановке совершения, способе насильственных действий, объекте преступного посягательства, личности потерпевшего, личности обидчика.

Ключевые слова: домашнее насилие; уголовное правонарушение; начальный этап расследования; тактические задачи; событие преступления; следователь; пострадавший; обидчик. 